\title{
Rancang Bangun Sistem Audit Mutu Internal Guna Optimalisasi Kinerja Penjaminan Mutu Perguruan Tinggi
}

\author{
${ }^{1}$ Istianah Muslim*, ${ }^{2}$ Maksum Rois Adin Saf, ${ }^{3}$ Rika Perdana Sari, ${ }^{4}$ Silvana Rasio Henim \\ ${ }^{1}$ Sistem Informasi, ${ }^{2,3,4}$ Teknik Informatika, Politeknik Caltex Riau \\ Jl. Umban Sari, No. 1, Rumbai, Pekanbaru, Indonesia \\ *e-mail: istianah@pcr.ac.id
}

(received: 6 April 2021, revised: 25 April 2021, accepted: 18 Mei 2021)

\begin{abstract}
Abstrak
Salah satu bentuk evaluasi pada Sistem Penjaminan Mutu Internal (SPMI) perguruan tinggi adalah pelaksanaan Audit Mutu Internal (AMI). AMI merupakan kegiatan rutin tahunan yang dilakukan untuk mengevaluasi kesesuaian pelaksanaan standar SPMI agar dapat menjaga dan meningkatkan budaya mutu di sebuah perguruan tinggi. Menyadari pentingnya peranan AMI, setiap perguruan tinggi harus mampu melaksanakan AMI dengan baik agar dokumentasi dan pelaksanaannya dapat dilakukan menyeluruh terhadap Standar SPMI yang telah ditetapkan. Namun demikian, keterbatasan sumber daya manusia, waktu dan biaya menjadi kendala dan tantangan dalam pelaksanaan AMI. Banyaknya indikator yang harus diaudit dengan kompleksitas tahapan dalam pelaksanaan serta dokumentasi hasil AMI yang membutuhkan ruang penyimpanan yang besar tetapi berpotensi hilang dan rusak menjadi hambatan dalam mewujudkannya. Mengatasi permasalahan tersebut, dirancang suatu sistem informasi berbasis website yang mampu mendigitalisasi sistem dan mengotomatisasi pelaksanaan AMI agar menjadi efektif dan efisien dengan menggunakan metode prototyping. Sistem ini dirancang dinamis agar dapat disesuaikan dengan kebutuhan perguruan tinggi lainnya yang menggunakan model implementasi yang sama. Dengan diterapkannya sistem informasi ini dengan studi kasus Politeknik Caltex Riau (PCR), diperoleh hasil bahwa pelaksanaan AMI di PCR terbukti menjadi efektif dan efisien dari sisi waktu, pelaksanaan, otomatisasi pembuatan laporan yang dibutuhkan, pengukuran tingkat kedalaman indikator, dokumentasi dan visualisasi hasil AMI, pelaksanaan tindak lanjut hasil AMI serta konsistensi pelaksanaan AMI. Selain itu, sistem ini juga berhasil mengoptimalisasi kinerja SPMI di PCR melalui sistem e-SPMI yang telah dirancang dan diimplementasikan sebelumnya di PCR. Sistem informasi ini juga telah memenuhi seluruh aspek fungsional yang diharapkan dan memiliki tingkat kebergunaan yang sangat baik mencapai $87 \%$.
\end{abstract}

Kata kunci: audit mutu internal, metode prototyping, penjaminan mutu, sistem informasi, website.

\begin{abstract}
One type of evaluation of the SPMI is the implementation of Internal Quality Audit (AMI). AMI is an annual routine activity conducted to evaluate the conformity of SPMI standards in order to improve the quality culture in a university. Recognizing the importance of the role of AMI, every university must be able to implement the AMI properly so that documentation and implementation can be done thoroughly against the SPMI standards that have been set. Nevertheless, the limitations of human resources, time and cost become obstacles and challenges in the implementation of AMIs. The number of indicators that must be audited with the complexity of stages in the implementation and documentation of AMI results that require large storage space but potentially lost and damaged becomes an obstacle in making it happen. To solve these problems, a website-based information system is designed that is able to digitize the system and automate the implementation of AMIs in order to be effective and efficient using prototyping method. With the implementation of this information system with the case study of Politeknik Caltex Riau (PCR), it was obtained that the implementation of AMI in PCR proved to be effective and efficient in terms of time, implementation, automation of the required data, measurement of the depth of indicators, documentation and visualization of AMI results, implementation of follow-up of AMI results and consistency of AMI
\end{abstract}


implementation. In addition, the system also managed to optimize spmi performance in PCR through e-SPMI system that has been designed and implemented previously in PCR. This information system has also fulfilled all expected functional aspects and has an excellent usability rate of up to $87 \%$.

Keywords: internal quality audit, prototyping method, quality insurance, information system, website

\section{Pendahuluan}

Kompleksitas tahapan dan dinamisasi pelaksanaan Sistem Penjaminan Mutu Internal (SPMI), menuntut perguruan tinggi untuk selalu berinovasi dan fleksibel menghadapi semua perubahan aturan dan kebijakan yang ada. Hal ini berutujuan agar perguruan tinggi selalu dapat menjaga kualitas sebagai bentuk perwujudan budaya mutu yang menjadi otonomi perguruan tinggi [1] [2] [3]. Salah satu tahapan yang memiliki fungsi penting di dalam SPMI adalah Audit Mutu Internal (AMI). Pelaksanaan AMI menjadi penting karena AMI merupakan salah satu bentuk evaluasi SPMI dan output yang dihasilkan menunjukkan bagaimana kesesuaian dan efektivitas keterlaksanaan Standar SPMI yang telah ditetapkan serta menjadi refleksi evaluasi diri bagi setiap perguruan tinggi [4]. Besarnya peranan AMI dalam mengevaluasi implementasi budaya mutu di sebuah perguruan tinggi, harus diikuti dengan proses yang sangat baik. Hal ini bertujuan agar dokumentasi dari pelaksanaan AMI tersebut dapat tersimpan dengan baik dan proses pelaksanaannya efektif dan efisien. Namun, keruwetan, kerumitan, dan keterbatasan sumber daya menjadi kendala utama untuk mewujudkan pelaksanaan AMI yang efektif dan efisien. Banyaknya indikator yang harus diaudit berdasarkan Standar Dikti yang telah ditetapkan, keluasan tingkat kedalaman evaluasi indikator, lamanya waktu yang dibutuhkan, dokumentasi laporan yang berpotensi rusak dan hilang, serta rendahnya efektivitas pelaksanaan monitoring dan tindak lanjut hasil AMI menjadi tantangan dalam pelaksanaan AMI di setiap perguruan tinggi [2] [3] [5] [6].

Mengatasi permasalahan tersebut, perancangan sistem informasi berbasis website menjadi solusi yang mampu menyelesaikan berbagai hambatan dan tantangan yang dihadapi, mendigitalisasi sistem dan mengakomodir keseluruhan tahapan pelaksanaan AMI agar menjadi efektif dan efisien [2] [7]. Penelitian terkait mengenai hal ini telah banyak dilakukan oleh peneliti terdahulu dan telah diimplementasikan di berbagai perguruan tinggi yang ada di Indonesia, antara lain Universitas Muhammadiyah Malang [2], STMIK PalComTech [3], Universitas Budi Luhur [4], STMIK Balikpapan [5], Unjani [6], Politeknik Negeri Bandung [8], Kampus MDP [9], Institut Agama Islam Ibrahimy [10], Universitas Sam Ratulangi [11], Institut Pertanian Bogor, Universitas Gajah Mada dan Universitas Brawijaya [16] . Selain itu, juga ada perancangan model sistem informasi AMI dan SPMI untuk keseluruhan perguruan tinggi [7] [12]. Meskipun demikian, sistem informasi yang telah dirancang tersebut, masih membutuhkan pengembangan sistem yang lebih komprehensif agar dapat mengakomodir seluruh tahapan pelaksanaan AMI yang tidak hanya pada bagian persiapan maupun pelaporan, tetapi juga pada tahapan pelaksanaan sehingga pelaksanaan AMI dapat fleksibel serta lebih efektif dan efisien untuk diterapkan di seluruh perguruan tinggi di Indonesia.

Berdasarkan hal tersebut, dalam penelitian ini dilakukan perancangan sistem informasi AMI yang bersifat fleksibel dan dinamis menyesuaikan kebutuhan setiap perguruan tinggi. Tujuannya adalah untuk memudahkan perguruan tinggi secara keseluruhan menghadapi dinamisasi dan kompleksitas dalam mengimplementasikan SPMI dan pelaksanaan AMI sehingga mampu menjadi sarana yang efektif untuk menumbuhkembangkan budaya mutu pada setiap perguruan tinggi dan meningkatkan daya saing secara global [1].

Banyaknya kebutuhan dan informasi yang harus dianalisis secara tepat, perancangan model sistem yang harus disetujui terlebih dahulu oleh pengguna dan dibutuhkannya evaluasi menyeluruh terhadap hasil perancangan sistem, sistem ini dibangun dengan menggunakan metode prototyping karena dinilai sesuai dengan karakteristik kebutuhan pembangunan sistem tersebut [2] [13] [14] [15]. Selain itu, pemilihan metode ini dilakukan karena AMI merupakan proses yang melibatkan banyak stakeholder sehingga pembangunannya dari awal harus melibatkan pengguna dan evaluasi dari pengguna pada setiap tahapannya agar sistem tersebut sesuai dengan kebutuhan pengguna dan ketetapan yang ada dari Kemenristekdikti. Untuk kebutuhan penelitian ini, studi kasus untuk implementasi sistem ini dilakukan di Politeknik Caltex Riau (PCR) dan menjadi bagian dalam sistem e-SPMI yang telah dirancang dan diimplementasikan sebelumnya di PCR. 
Tujuan penelitian ini adalah agar pelaksanaan AMI menjadi lebih efektif dan efisien, di mana AMI dapat dilakukan dengan waktu yang singkat, memudahkan auditor dalam melaksanakan audit, baik audit dokumen maupun audit kepatuhan, digitalisasi dan otomatisasi pembuatan dan penyimpanan laporan yang dihasilkan, monitoring tindakan koreksi dan tindak lanjut hasil AMI dapat dilakukan lebih mudah dan real time, dokumentasi pelaksanaan RTM dapat tersimpan secara digital dan AMI dapat dengan mudah diimplementasikan untuk keseluruhan standar yang ada di perguruan tinggi [2] [5]. Sistem ini juga diharapkan mampu untuk memvisualisasikan hasil AMI yang dapat diakses kapanpun dan dimanapun sehingga dapat dijadikan rujukan pengambilan keputusan oleh pemangku kepentingan. Hasil dari penelitian ini diharapkan dapat menjadi inspirasi, acuan dan pengetahuan bagi perguruan tinggi dan instansi lainnya mengenai implementasi sistem informasi AMI dan e-SPMI secara keseluruhan. Model sistem informasi yang dihasilkan dapat digunakan lebih luas karena desain sistem dirancang dinamis dan fleksibel sesuai kebutuhan perguruan tinggi [8].

\section{Tinjauan Literatur}

Audit Mutu Internal (AMI) merupakan salah satu cara evaluasi yang paling efektif untuk digunakan sebagai cara memperoleh ruang peningkatan mutu Pendidikan tinggi sebuah perguruan tinggi [16] [17]. AMI digunakan untuk mengukur tingkat kesesuaian antara pelaksanaan penyelenggaraan Pendidikan tinggi dengan standar SPMI yang telah ditetapkan oleh sebuah perguruan tinggi. Pelaksanaan AMI secara khusus diatur di dalam Permenristekdikti Nomor 62 Tahun 2016 Pasal 5, di mana AMI adalah proses evaluasi yang termasuk di dalam siklus PPEPP yang diatur pada UU Nomor 12 Tahun 2012 Bab III tentang Penjaminan Mutu. Siklus PPEPP merupakan siklus di dalam manajemen SPMI yang meliputi Penetapan standar (P), Pelaksanaan Standar (P), Evaluasi pelaksanaan standar (E), Pengendalian pelaksanaan standar (P), dan Peningkatan standar (P) [18].

Pelaksanaan AMI terdiri dari beberapa tahapan yaitu Perencanaan AMI, Pelaksanaan AMI, Laporan AMI, serta Rapat Tinjauan Manajemen (RTM) dan Evaluasi Kegiatan AMI [16]. Adapun tahapan detail dalam perencanaan AMI adalah perumusan tujuan dan kebijakan AMI yang akan dilakukan, penentuan ruang lingkup pelaksanaan AMI, penentuan auditor yang bertugas berdasarkan ketentuan penugasan auditor, penentuan tempat dan jadwal pelaksanaan dan persiapan seluruh dokumen yang dibutuhkan. Setelah keseluruhan tahapan perencanaan ini disepakati maka selanjutnya dilakukan tahapan pelaksanaan AMI yang meliputi pelaksanaan audit dokumen dengan mengidentifikasi hasil laporan evaluasi diri, penyusunan daftar checklist (daftar pertanyaan) yang diajukan berdasarkan hasil audit dokumen, pelaksanaan audit lapangan atau visitasi yang diawali dengan peninjauan hasil AMI sebelumnya, wawancara dan pengumpulan bukti, perumusan hasil temuan audit, rapat penutupan pelaksanaan audit dan penyusunan laporan hasil AMI. Tahapan terakhir adalah Rapat Tinjauan Manajemen berdasarkan laporan hasil AMI, perencanaan peningkatan mutu di masa mendatang yang dilakukan oleh manajemen perguruan tinggi dan penyusunan laporan RTM.

Kompleksitas tahapan pelaksanaan AMI tersebut tidak dapat terwujud dengan baik jika perguruan tinggi tidak memiliki komitmen yang kuat untuk mewujudkan budaya mutu di perguruan tinggi. Dibutuhkan komitmen manajemen dan dukungan semua pihak untuk mewujudkan AMI yang berkualitas baik agar SPMI dapat dilaksanakan secara optimal di perguruan tinggi tersebut. Perguruan tinggi juga harus memiliki organ yang berfungsi untuk mengoptimalkan kinerja penjaminan mutu perguruan tinggi, auditor yang jumlahnya memadai dan kelengkapan sarana yang mendukung pelaksanaan AMI agar dokumentasi hasilnya dapat tersimpan secara baik dan tidak memiliki potensi rusak dan hilang.

Hasil yang diperoleh dari pelaksanaan AMI menjadi potret diri, baik bagi program studi maupun institusi. Hal ini juga memberikan dampak terhadap pencapaian audit eksternal (akreditasi). Semakin baik institusi tersebut melaksanakan AMI, semakin mudah bagi institusi tersebut untuk mengukur ketercapaian akreditasi. Salah satu perguruan tinggi yang berhasil meningkatkan capaian akreditasi berdasarkan kualitas pelaksanan AMI dan SPMI secara keseluruhan adalah Universitas Brawijaya (UB) [16]. Berdasarkan milestone tahunan pencapaian akreditasi, UB berhasil menambah jumlah prodi terakreditasi A menjadi 72 di tahun 2018 yang sebelumnya berjumlah 37 di tahun 2014. Selain itu, UB juga berhasil mempertahankan AIPT A dan menjadi peringkat 5 versi Dikti sejak tahun 2016. Praktik baik dari implementasi AMI di UB tersebut memberi dampak terhadap peningkatan atmosfir 
akademik, penguatan budaya mutu dan pengurangan ketidaksesuaian standar kinerja yang tidak diharapkan [16].

Besarnya peranan AMI bagi sebuah institusi, membutuhkan peningkatan kualitas pelaksanaan AMI itu sendiri. AMI yang dilakukan secara manual tidak lagi menjadi efektif dan efisien untuk mengevaluasi seluruh Standar Dikti yang telah ditetapkan dengan minimal 24 Standar di setiap perguruan tinggi. Penggunaan sistem informasi menjadi solusi yang diharapkan untuk peningkatan kualitas pelaksanaan AMI. Pemanfaatan sistem informasi ini telah dilakukan di berbagai perguruan tinggi berdasarkan keunikan dan karakteristik sistem manajemen dari setiap Perguruan Tinggi.

Berdasarkan penelusuran terhadap hasil penelitian dan model sistem informasi AMI pada beberapa perguruan tinggi tersebut, dapat diketahui bahwa sistem informasi yang dirancang untuk peningkatan efektifitas pelaksanaan AMI di beberapa perguruan tinggi telah menunjukkan hasil yang baik dan mampu meningkatkan kinerja bagian penjaminan mutu. Meskipun demikian, sistem informasi yang telah dirancang tersebut, masih membutuhkan pengembangan sistem yang lebih komprehensif agar dapat mengakomodir seluruh tahapan pelaksanaan AMI yang tidak hanya pada bagian persiapan maupun pelaporan, tetapi juga pada seluruh tahapan pelaksanaan sehingga pelaksanaan AMI dapat fleksibel serta lebih efektif dan efisien.

Hal ini menjadi tantangan dalam penelitian ini, yakni bagaimana menghasilkan sistem informasi yang diharapkan mampu mendigitalisasi sistem dan pelaksanaan AMI secara keseluruhan yang ada di perguruan tinggi. Sistem yang dibangun mengakomodir semua kebutuhan dalam pelaksanaan AMI hingga pelaksanaan RTM dan monitoring tindakan koreksi yang dilakukan oleh Auditee sesuai dengan model Kebijakan SPMI yang ditetapkan di pada masing-masing perguruan tinggi. Harapannya, pada saat pelaksanaan AMI, otomatisasi data akan menjadi bagian yang memudahkan Auditee dan Auditor dalam mengumpulkan dan menganalisis data yang ada. Selain itu, dokumentasi laporan AMI dan PTK akan menjadi lebih baik dan konsisten dari setiap pelaksanaannya.

Untuk mewujudkan hal tersebut, model SPMI yang digunakan untuk menjadi acuan dalam perancangan sistem informasi AMI ini adalah model SPMI yang diterapkan di Politeknik Caltex Riau yang juga telah menerapkan e-SPMI. Adapun model SPMI di PCR dapat dilihat pada Gambar 1.

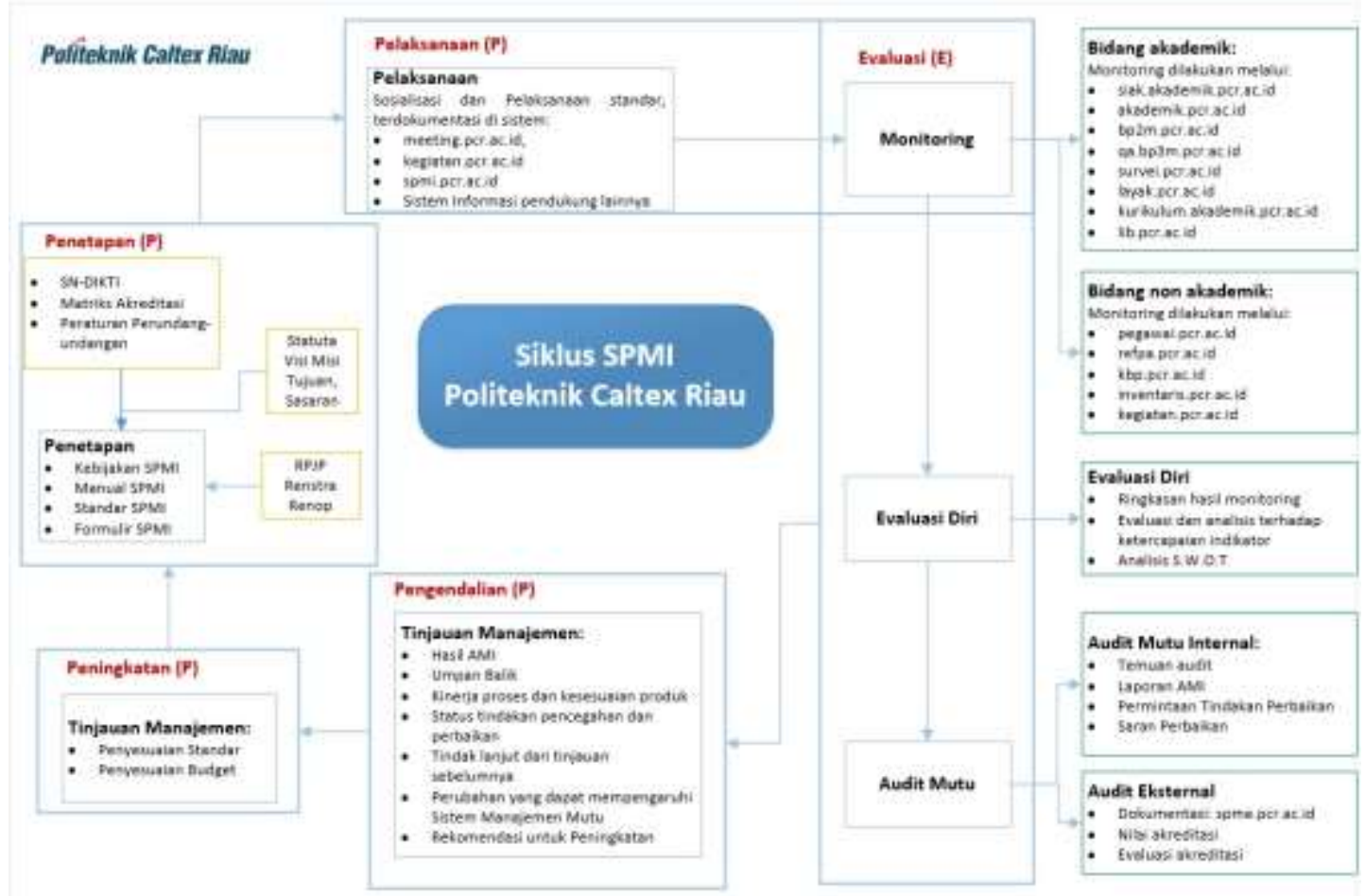

Gambar 1. Pelaksanaan AMI di dalam Siklus SPMI PCR

Sistem ini juga akan terintegrasi dengan e-SPMI yang sebelumnya telah diimplementasikan di PCR sehingga Pimpinan akan mudah untuk melakukan pengambilan keputusan terhadap kebijakan 
mutu PCR secara keseluruhan. Dalam pelaksanaannya nanti, sistem ini juga akan terintegrasi dengan database sistem informasi yang ada di PCR, terkait sistem akademik, sistem kepegawaian, sistem penelitian dan pengabdian masyarakat, sistem PMB, sistem tracer study, sistem keuangan dan sistem meeting, sistem Kerjasama, sistem kegiatan dan berbagai sistem lainnya yang ada di PCR.

\section{Metode Penelitian}

Untuk dapat memandu penelitian yang terarah dan tujuan yang telah ditetapkan dapat tercapai dengan baik, kerangka kerja penelitian yang dilakukan dalam penelitian ini dapat dilihat pada Gambar 2.

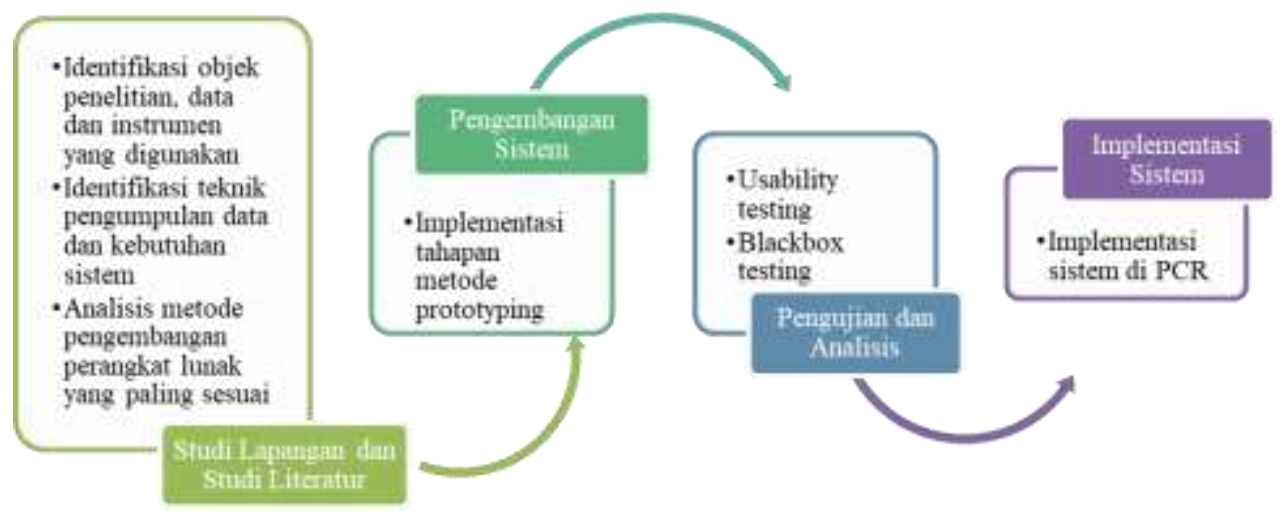

Gambar 2. Metodologi Penelitian

Rincian mengenai metodologi penelitian tersebut adalah:

1. Studi Lapangan

Dalam melaksanakan studi lapangan, hal-hal yang dilakukan adalah:

a. Identifikasi Objek Penelitian, Data dan Instrumen

Objek penelitian ini adalah Badan Perencanaan, Pengembangan dan Penjaminan Mutu (BP3M) Politeknik Caltex Riau. Data dan Instrumen yang digunakan pada penelitian ini adalah Panduan AMI, Dokumen SPMI, Laporan AMI, Laporan RTM dan integrasi data keseluruhan sistem informasi yang ada di PCR.

b. Teknik Pengumpulan Data

Penelitian ini menggunakan teknik wawancara, dokumentasi dan observasi untuk melakukan pengumpulan data. Teknik wawancara dilakukan dengan Pimpinan PCR, auditor internal, Auditee dan BP3M untuk mendapatkan spesifikasi kebutuhan sistem AMI. Teknik dokumentasi dilakukan dengan mengumpulkan dokumen tertulis dan menganalisis data-data terkait AMI yang telah dilaksanakan di PCR. Teknik observasi dilakukan dengan melakukan pengamatan langsung atau simulasi pelaksanaan AMI sehingga situasi dan keberadaan objek penelitian dapat diketahui dengan jelas.

2. Studi Literatur

Dalam pelaksanaan studi literatur ini, dilakukan kajian terhadap referensi buku, jurnal, laporan penelitian atau karya ilmiah yang berhubungan dengan Audit Mutu Internal dan metode prototyping. Teori-teori dasar mengenai kedua hal tersebut, dikaji secara mendalam dan diimplementasikan untuk tahapan penelitian selanjutnya.

3. Perancangan Prototyping dan Pengembangan Sistem

Secara keseluruhan, tahapan dalam penyelesaian sistem dilaksanakan pada bagian ini. Proses rancang bangun sistem mengikuti metode pengembangan prototyping. Adapun tahapan di dalam metode pengembangan prototyping adalah analisis dan identifikasi seluruh kebutuhan, pengembangan dan evaluasi prototype, pengkodingan sistem dengan Bahasa pemograman, pengujian dan evaluasi sistem dan implementasi. Dalam pelaksanaannya, pengembangan sistem ini dilakukan dengan beberapa kali iterasi sesuai dengan persetujuan pengguna terhadap rancangan yang dihasilkan. Dalam perancangannya, sistem dirancang dinamis agar dapat dikustomisasi dengan kebutuhan perguruan tinggi lainnya yang menggunakan model implementasi yang sama.

4. Pengujian dan Analisis 
Pengujian dilakukan dengan 2 bentuk pengujian, yaitu usability testing dengan metode wawancara dan kuesioner dan blackbox testing. Hasil pengujian usability testing yang diharapkan adalah 85-100\% dengan kualifikasi sangat baik [19] dan menggunakan teori Jacob Nielsen [20] dan blackbox testing $100 \%$. Kedua pengujian tersebut melibatkan pengguna yang nantinya akan dilakukan pemilihan sampling menggunakan salah satu teknik nonprobability sampling, yaitu purposive sampling. Jumlah sampel dalam penelitian ini menggunakan perhitungan perhitungan Slovin. Dalam hal ini jumlah seluruh populasi yang diteliti adalah 45 orang yang terdiri atas auditor dan jumlah staf yang memperoleh tugas tambahan (jabatan struktural di PCR) dan staf di BP3M PCR. Berdasarkan perhitungan slovin dengan menggunakan margin kesalahan 5\%, maka jumlah sampel yang diteliti adalah 40 orang.

5. Implementasi Sistem

Selanjutnya sistem diimplementasikan di Politeknik Caltex Riau untuk dievaluasi lebih lanjut terhadap dampak implementasi sistem tersebut.

\section{Hasil dan Pembahasan}

Hasil analisis dan identifikasi kebutuhan sebagai tahapan awal dalam metode prototyping berdasarkan studi literatur dan studi lapangan yang diperoleh dari objek, data dan instrumen yang diidentifikasi serta pengumpulan data yang dilakukan dengan observasi langsung, dokumentasi dan wawancara terhadap pengguna terkait sistem Audit Mutu Internal PCR, dalam hal ini pengguna sistem adalah Auditee, Auditor, Admin, Staf PCR, diperoleh hasil sebagai berikut:

1. Sistem yang dihasilkan harus mengacu terhadap Pedoman Audit Mutu Internal (AMI) yang dikeluarkan oleh Direktorat Penjaminan Mutu, Direktorat Jenderal Pembelajaran dan Kemahasiswaan, Kementrian Riset, Teknologi, dan Pendidikan Tinggi tahun 2018.

2. Sistem yang dihasilkan terintegrasi dengan sistem e-SPMI PCR, di mana sistem ini telah menghasilkan fitur untuk login, pengaturan pengguna sistem, penyimpanan dokumen SPMI, pengaturan penanggung jawab dari masing-masing indikator dari Standar SPMI yang telah ditetapkan, serta fitur untuk visualisasi dashboard dari sistem tersebut. Model integrasi ini menunjukkan pembaharuan dari sistem AMI yang telah dikembangkan sebelumnya di beberapa perguruan tinggi.

3. Sistem menghasilkan fitur yang memenuhi kebutuhan fungsional terkait AMI, yang dimulai dengan pelaksanaan Evaluasi Diri dan analisis SWOT, persiapan AMI, pelaksanaan AMI, pembuatan Laporan AMI dan pelaksanaan Rapat Tinjauan Manajemen (RTM). Adapun kebutuhan fungsional terkait hal tersebut adalah:

a. Pengelolaan Data User yang memiliki fitur tambah, edit, hapus oleh Admin

b. Pelaksanaan Evaluasi Diri.

Adapun fitur yang dibutuhkan adalah:

1) Penjadwalan pelaksanaan evaluasi diri oleh admin dengan pengisian tanggal mulai dan tanggal selesai, edit dan hapus jadwal periode evaluasi diri tersebut.

2) Pengisian evaluasi diri berdasarkan indikator oleh Auditee

3) Pengisian Analisis SWOT oleh Auditee

4) Tampilan hasil pengisian evaluasi diri yang dapat diakses oleh seluruh user

c. Persiapan dan Pelaksanaan AMI

Adapun fitur yang dibutuhkan adalah:

1) Penjadwalan pelaksanaan AMI oleh admin dengan pengisian tanggal mulai dan tanggal selesai, edit dan hapus jadwal periode AMI serta pengisian Standar yang diaudit dan jenis AMI yang dilakukan (akademik atau non akademik).

2) Penentuan Auditor yang bertugas mengaudit oleh admin

3) Pelaksanaan AMI

Adapun rincian kegiatan yang dilakukan dalam proses pelaksanaan AMI adalah:

a) AMI dapat dilakukan jika Auditee telah menyelesaikan evaluasi diri terhadap indikator yang akan diaudit. Selanjutnya Auditor melakukan audit dokumen dengan mengidentifikasi unggahan dokumen oleh Auditee dan memeriksa hasil evaluasi diri yang telah diisi oleh Auditee untuk menghasilkan daftar checklist. Selain itu, Auditor 
juga melakukan peninjauan efektivitas terhadap hasil AMI pada periode sebelumnya dengan mencentang oke jika sudah terlaksana atau periode selanjutnya jika belum terlaksana. Selanjutnya Auditor melakukan audit lapangan (visitasi) secara online dengan memilih salah satu dari 3 model fitur yang tersedia, yaitu Diskusi Tanya Jawab, Persetujuan, Hasil Akhir. Pada Fitur Diskusi Tanya Jawab, terdapat chatting antara Auditor dan Auditee secara online. Hasil chatting menampilkan daftar pertanyaan (checklist pertanyaan) yang diajukan dan jawaban dari Auditee dalam bentuk history tanya jawab. Dalam penentuan hasil akhir, Auditor memilih 4 pilihan status, yaitu melampaui (M), tercapai (T), observasi (OB), dan ketidaksesuaian (KTS) dan dilanjutkan dengan mengisi deskripsi/ uraian temuan sesuai dengan panduan penulisan pernyataan temuan. Jika pilihan statusnya adalah observasi (OB) dan ketidaksesuaian (KTS), Auditor harus menuliskan akar penyebab dan akibat.

b) Setelah penentuan hasil akhir, jika statusnya adalah OB dan KTS, selanjutnya Auditee harus mengisi Rencana Tindakan Perbaikan dan Jadwal Target Penyelesaian. Jika statusnya adalah Melampaui dan Terpenuhi Auditee tidak perlu mengisi bagian tersebut dan status audit otomatis dinyatakan selesai.

c) Setelah Auditee mengisi bagian b), selanjutnya Auditor menentukan status akhir dari indikator dengan mencentang atau tidak mencentang pada indikator yang berstatus observasi atau ketidaksesuaian. Jika dicentang, maka indikator tersebut akan masuk ke dalam indikator yang akan diperiksa di AMI selanjutnya, jika tidak dicentang auditor akan melakukan pengisian kembali pada waktu yang telah ditentukan Auditee untuk menyatakan audit selesai atau dibawa ke periode selanjutnya.

d) Pengelolaan Data Temuan

Pada bagian ini, user sama-sama dapat mengetahui status hasil audit yang telah dilakukan. Selanjutnya terdapat pilihan untuk mengetahui status temuan yang ada, terdapat 3 pilihan, yaitu (1) Rencana Tindakan Koreksinya (RTK) sudah dilaksanakan dan sudah disetujui Auditor dan BP3M, (2) RTK sudah dilaksanakan namun belum disetujui Auditor dan BP3M, (3) status RTK belum dilaksanakan. Selain itu, juga terdapat fitur untuk notifikasi batas waktu pelaksanaan RTK bagi Auditee sesuai tanggal yang telah diinputkan pada saat mengisi Rencana Tindakan Koreksi (RTK) sehingga menjadi pengingat bahwa RTK tersebut belum dilaksanakan dan harus diselesaikan.

e) Pengisian Saran Perbaikan

Auditor memiliki fitur untuk pengisian saran perbaikan untuk prodi atau bagian yang diaudit.

f) Tampilan Hasil AMI

Tersedia fitur untuk menampilkan hasil AMI yang telah terlaksana dan dapat diakses oleh seluruh user.

d. Pembuatan Laporan AMI

Tersedia fitur otomatisasi pembuatan laporan AMI secara keseluruhan.

e. Pelaksanaan RTM

Setelah AMI selesai, selanjutnya dilaksanakan RTM untuk mengevaluasi hasil AMI dan hasil umpan balik selama periode AMI tersebut yang dapat diakses oleh user yang telah diinputkan oleh Admin. Adapun isian yang dibutuhkan untuk dokumentasi pelaksanaan RTM adalah daftar peserta, waktu dan tempat pelaksanaan, serta 7 agenda RTM sesuai panduan AMI.

Tahapan selanjutnya adalah perancangan dengan menggunakan use case diagram. Aktor yang terlibat di dalam pelaksanaan AMI adalah Ka SPMI, Auditor, Auditee dan e-SPMI. Ka SPMI dapat melakukan kelola jadwal AMI dan melihat hasil AMI. Selanjutnya Auditor dapat melakukan audit, melakukan diskusi tanya jawab, mengisi saran perbaikan, kelola rencana tindakan perbaikan dan kelola laporan hasil audit. Sedangkan Auditee melakukan evaluasi diri yang sudah terdapat pada sistem e-SPMI, melakukan diskusi tanya jawab, kelola rencana tindakan perbaikan, dan melihat hasil AMI. Sistem ini nantinya akan terintegrasi dengan e-SPMI yang menampilkan hasil evaluasi diri dan keseluruhan dokumen SPMI. Use case diagram sistem AMI ini dapat dilihat pada Gambar 3. 


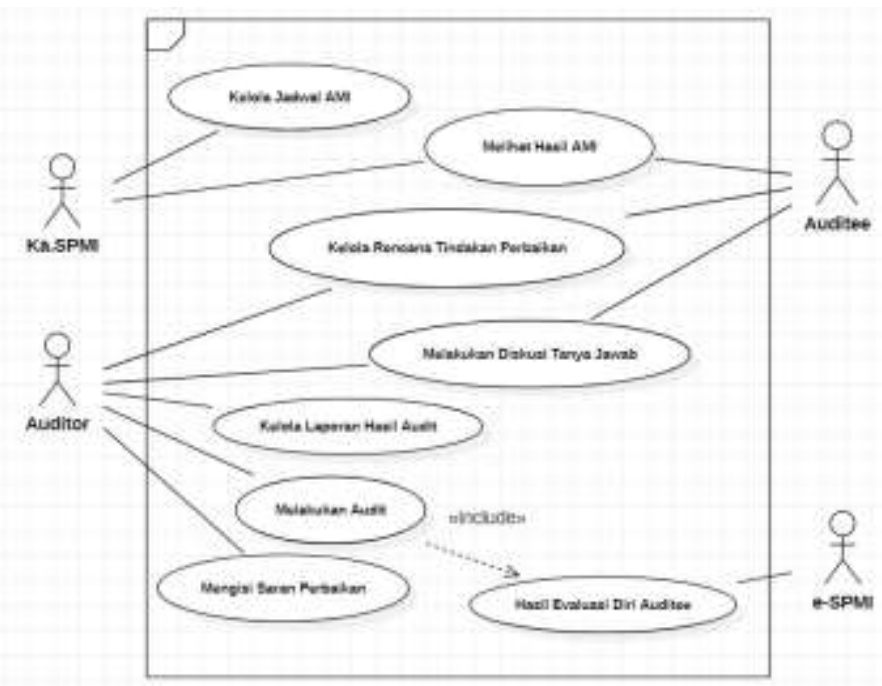

Gambar 3. Use Case Diagram Sistem AMI

Selanjutnya dilakukan rancangan prototyping dan antarmuka sistem. Dalam tahapan ini, dilakukan 4 kali iterasi hingga diperoleh tampilan yang telah disetujui oleh seluruh user. Adapun beberapa tampilan sistem tersebut adalah:

1. Halaman Login

Login pada sistem ini menerapkan single sign-on (SSO) menggunakan gmail yang telah terintegrasi dengan sistem kepegawaian untuk pengaturan posisi pegawai di PCR. Ketika user memiliki hak akses lebih dari 1, maka setelah login akan ada pilihan akses, yaitu Auditor (jika memiliki sertifikat auditor), Admin (Ka SPMI, Ka BP3M dan staf SPMI) dan Pegawai di mana setiap pilihan memiliki hak akses yang berbeda. Tampilan login dapat dilihat pada Gambar 4 .
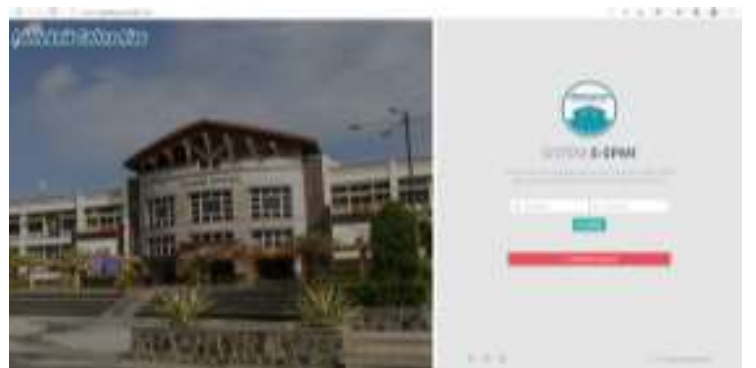

\section{Gambar 4. Halaman Tampilan Awal Sistem untuk Login}

2. Halaman Pengisian Evaluasi Diri

Halaman ini merupakan interpretasi dari analisis kebutuhan terhadap pelaksanaan Evaluasi Diri. Pada halaman ini terdapat fitur yang ditujukan kepada Auditee untuk mengisi evaluasi diri dari setiap indikator yang menjadi tanggung jawabnya. Setiap Auditee mencentang salah satu pilihan skala capaian yang ditetapkan pada tahapan penetapan Standar SPMI. Pada bagian ini juga tersedia bagian untuk pengisian analisis capaian. Selain itu juga terdapat bagian capaian real yang otomatis dari integrasi sistem terkait yang ada di PCR. Tampilan halaman ini dapat dilihat pada Gambar 5. 


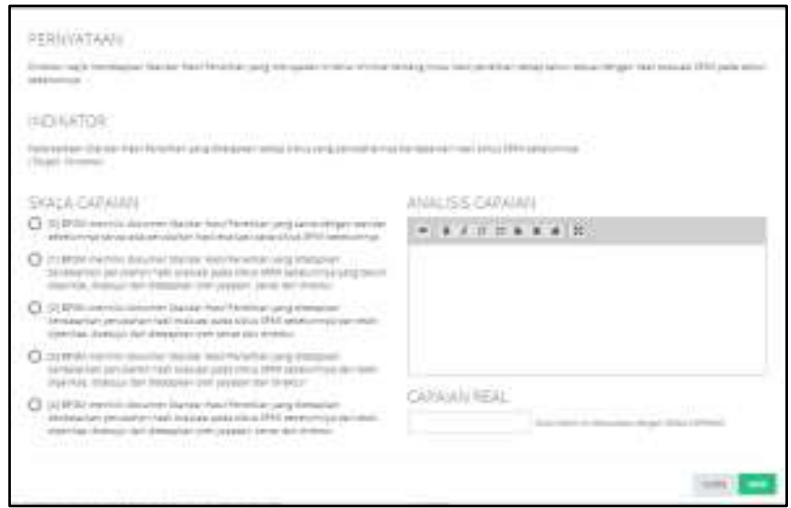

Gambar 5. Tampilan Halaman Pengisian Evaluasi Diri

3. Halaman Pelaksanaan AMI dan Pengisian Rencana Tindakan Koreksi

Halaman ini merupakan interpretasi analisis kebutuhan terhadap pelaksanaan AMI. Pada halaman ini ditampilkan nama standar yang diaudit, periode tahun pelaksanaan, nama Auditee, asal prodi, jenis AMI, jenis data dan nama auditor yang bertugas di bagian kiri atas. Sedangkan pada bagian kanan atas terdapat isi pernyataan ayat pada standar tersebut, indikator yang diukur, pilihan skala capaian, jenis indikator apakah IKU atau IKT, target yang diharapkan, capaian real jika itu adalah data kuantitatif, pilihan skala capaian dan analisis capaian pada saat evaluasi diri, serta file pendukug yang diunggah pada saat evaluasi diri. Selanjutnya terdapat fitur untuk pelaksanaan audit lapangan berupa diskusi tanya jawab, persetujuan dan penetapan hasil akhir yang ditunjukkan pada Riwayat status indikator pada bagian kanan bawah. Selanjutnya hasil deskripsi/ uraian temuan, akar penyebab dan akibat yang diisi oleh Auditor yang dapat dilihat pada bagian tengah kiri. Selanjutnya Rencana Tindakan Perbaikan dan jadwal target penyelesaian yang diisi oleh Auditee untuk dicek kembali oleh Auditor pada bagian pelaksanaan tindakan perbaikan yang dapat dilihat pada bagian kiri bawah. Tampilan halaman pelaksanaan AMI ini dapat dilihat pada Gambar 6.

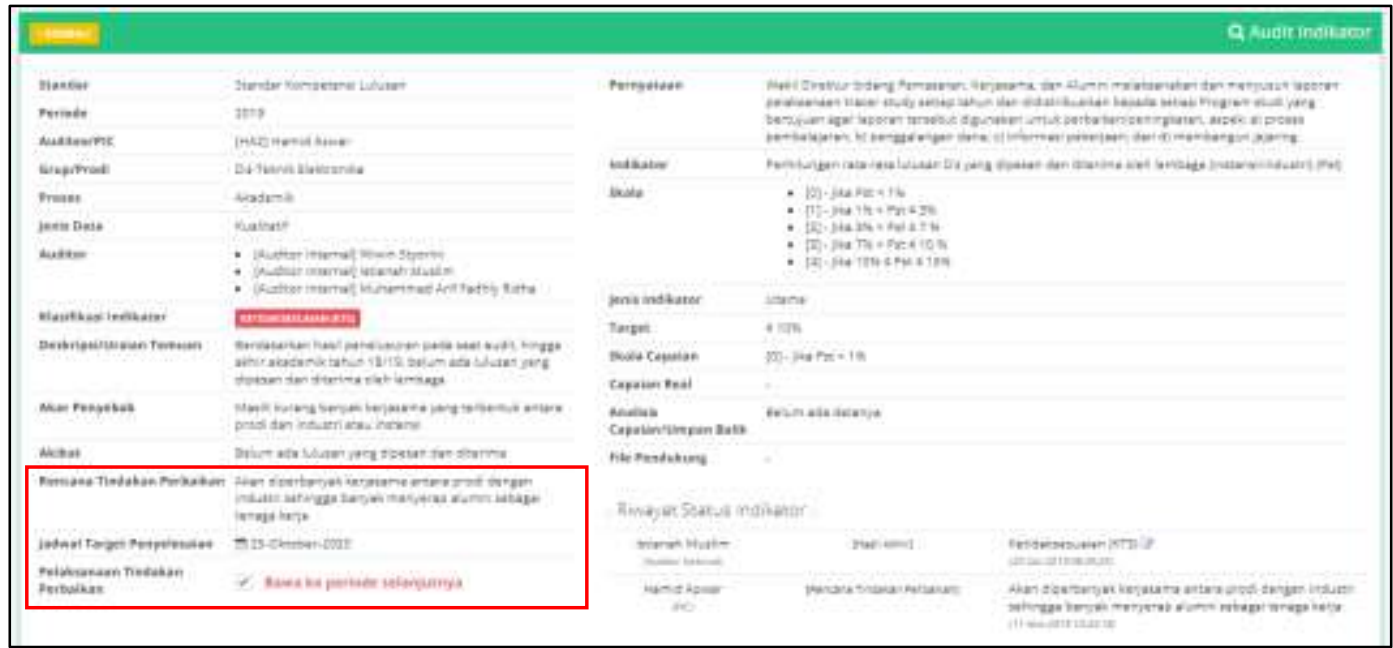

Gambar 6. Tampilan Halaman Pengisian Rencana Tindakan Koreksi

4. Halaman Tampilan Hasil AMI

Pada halaman ini terdapat fitur untuk menampilkan hasil AMI secara keseluruhan dengan pilihan tahun pelaksanaan, prodi atau bagian yang akan dipilih dan status indikator. Hasil AMI ditampilkan dalam bentuk grafik dan tabel setiap indikator dan hasil dari masing-masing prodi. Tampilan halaman ini dapat dilihat pada Gambar 7. 


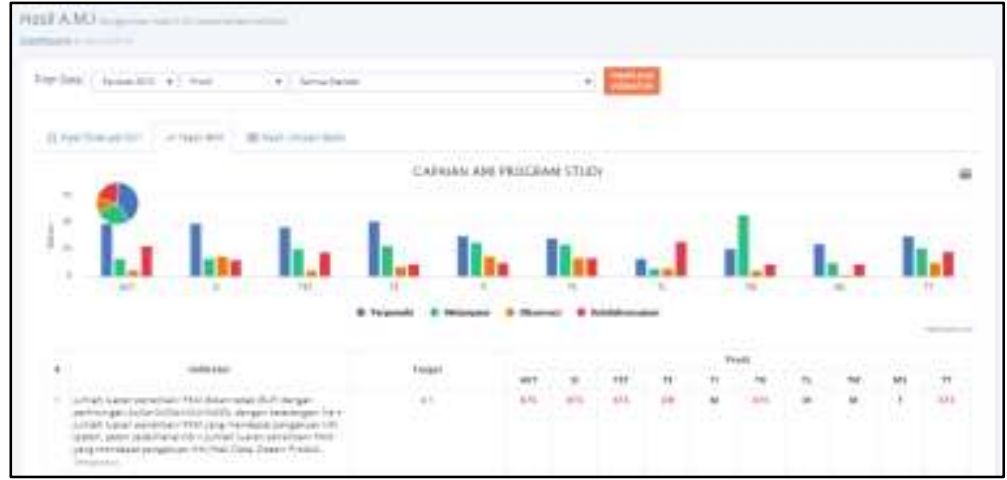

Gambar 7. Tampilan Halaman Hasil AMI

Tahap akhir pada implementasi metode protoyping adalah evaluasi dan analisis. Berdasarkan hasil wawancara dan kuesioner kepada pengguna sistem dalam hal ini adalah Auditee, Auditor, Administrator dan Pengguna Umum terhadap performa sistem yang telah dibangun dan sistem tersebut telah digunakan pada saat pelaksanaan AMI PCR baik bidang akademik maupun non akademik pada tahun 2019 dan 2020 diperoleh hasil bahwa:

1. Sistem dikategorikan sangat baik berdasarkan penilaian pengelola mutu dan manajemen di beberapa kampus di Indonesia melalui kuisioner yang disebarkan pada saat uji publik sistem menggunakan channel youtube PCR pada tanggal 5 Juni 2020 dan hasil kuisioner dari kunjungan beberapa kampus ke PCR. Penilaian sangat baik ini karena sistem tersebut telah memenuhi tahapan pelaksanaan AMI secara keseluruhan dan memiliki fitur yang fleksibel dan dinamis untuk diterapkan di seluruh perguruan tinggi. Sistem ini juga memiliki pembaharuan dan keunikan fitur yang mampu mengoptimalkan kinerja penjaminan mutu secara keseluruhan seperti fitur untuk pelaksanaan evaluasi diri, pelaksanaan AMI dan RTM yang mampu menghasilkan otomatisasi pembuatan laporan, digitalisasi pelaksanaan dan visualisasi hasil secara real time.

2. Sistem yang diterapkan telah sesuai dengan pedoman Audit Mutu Internal yang dikeluarkan oleh Kementerian Riset, Teknologi, dan Pendidikan Tingi tahun 2018.

3. Sistem yang dihasilkan mampu mengefesiensikan waktu pelaksanaan AMI yang sebelumnya dilaksanakan dalam waktu 30 hari untuk mengaudit seluruh indikator yang telah ditetapkan dan penyusunan laporan AMI, menjadi 5 hari untuk keseluruhan standar dan penyusunan laporannya. Artinya dapat mengefisiensikan waktu sebesar $83 \%$.

4. Keseluruhan fitur dapat berjalan sesuai dengan fungsi yang diharapkan dengan dilaksanakannnya pengujian fungsionalitas sistem dengan menggunakan pengujian blackbox. Sistem ini juga memiliki tingkat kebergunaan yang sangat baik mencapai $87 \%$ berdasarkan usability testing terhadap 5 komponen yaitu learnability, efficiency, memorability, errors dan satisfaction.

5. Sistem informasi ini dapat mempermudah pelaksanaan AMI secara keseluruhan dan dokumentasi hasil pelaksanaan dapat tersimpan dengan baik dan dapat diakses kapan saja secara terbuka kepada seluruh stakeholder yang berkepentingan terhadap hasil AMI.

6. Sistem ini mampu mempermudah civitas akademika untuk mengetahui capaian kinerja dan ruang-ruang perbaikan yang dapat dilakukan untuk perbaikan pada masa yang akan datang.

7. Untuk penyempurnaan sistem di masa mendatang, dibutuhkan beberapa pengembangan yaitu:

a. Pengembangan fitur untuk mengotomatisasi hasil AMI menjadi hasil analisis pengisian instrumen akreditasi perguruan tinggi (IAPT) 3.0 dan IAPS 4.0 agar penyusunan evaluasi diri akreditasi menjadi efektif dan efisien serta memiliki tingkat keakuratan yang tinggi.

b. Pengembangan fitur notifikasi hasil AMI ke email masing-masing Auditee untuk mempercepat penentuan ruang perbaikan di masa mendatang.

c. Penyediaan panduan atau fitur help yang user friendly agar ketika pengguna mengalami kendala dalam menggunakan sistem dapat dengan mudah untuk menyelesaikannya dengan hanya memperhatikan fitur tersebut.

d. Sistem dikembangkan berbasis android dengan fitur khusus untuk pelaksanaan evaluasi diri dan Pelaksanaan AMI sehingga lebih fleksibel dan tampilan menjadi lebih ringkas.

Selain itu, sistem yang dirancang ini mampu meningkatkan akreditasi program studi yang ada di PCR menjadi $70 \%$ prodi memperoleh akreditasi A hingga tahun 2021 karena mampu memperkuat budaya 
mutu di PCR, transparansi data dan informasi yang semakin baik dan berkurangnya ketidaksesuaian kinerja yang tidak diharapkan di PCR secara keseluruhan.

\section{Kesimpulan}

Kesimpulan dari pelaksanaan penelitian ini adalah sistem informasi Audit Mutu Internal yang dirancang dan telah diimplementasikan ini mampu mengoptimalisasi kinerja penjaminan mutu perguruan tinggi dan berhasil meningkatkan produktivitas sistem e-SPMI yang telah dirancang dan diimplementasikan sebelumnya di PCR. Sistem ini dirancang lebih komprehensif untuk mengakomodir seluruh tahapan pelaksanaan AMI sesuai pedoman Audit Mutu Internal yang dikeluarkan oleh Kemenristekdikti tahun 2018. Dengan adanya fitur yang terintegrasi mulai dari penetapan standar SPMI, pelaksanaan evaluasi diri, pelaksanaan AMI hingga pelaksanaan RTM yang mampu mengotomatisasi dan mendigitalisasi pelaksanaan dan pelaporannya, diperoleh hasil bahwa pelaksanaan AMI di PCR terbukti menjadi efektif dan efisien dari sisi waktu yang dapat diefisiensi hingga $83 \%$, kemudahan dan konsistensi dalam proses pelaksanaan, otomatisasi perolehan sumber data yang dibutuhkan, pengukuran tingkat kedalaman indikator menjadi lebih menyeluruh, dokumentasi penyimpanan secara digital, visualisasi hasil AMI secara real time, kemudahan dalam pelaksanaan tindak lanjut hasil AMI, dan dokumentasi pelaksanaan RTM menjadi lebih baik. Selain itu, dengan model perancangan sistem dan fitur yang fleksibel dan dinamis, sistem ini dapat diadopsi dengan melakukan penyesuaian terhadap kebutuhan perguruan tinggi lainnya yang menggunakan model implementasi yang sama. Berdasarkan pengujian performa dan fungsionalitas sistem, sistem informasi ini juga telah memenuhi seluruh aspek fungsional yang diharapkan dan telah memenuhi kebutuhan pengguna secara keseluruhan dan memiliki tingkat kebergunaan yang sangat baik mencapai $87 \%$. Dengan adanya sistem ini, program studi yang terakreditasi A di PCR mencapai $70 \%$ karena implementasi sistem ini mampu memperkuat budaya mutu di PCR, transparansi data dan informasi yang semakin baik dan berkurangnya ketidaksesuaian kinerja yang tidak diharapkan di PCR secara keseluruhan. Untuk pelaksanaan penelitian di masa mendatang, fokus penelitian dapat dilakukan pada pengembangan fitur untuk mengotomatisasi hasil AMI menjadi hasil analisis pengisian instrumen akreditasi perguruan tinggi (IAPT) 3.0 dan IAPS 4.0 agar penyusunan evaluasi diri akreditasi menjadi efektif dan efisien serta memiliki tingkat keakuratan yang tinggi dan perancangan sistem berbasis android pada pelaksanaan evaluasi diri dan pelaksanaan AMI.

\section{Ucapan Terima Kasih}

Terimakasih kami sampaikan kepada Bagian Penelitian dan Pengabdian Masyarakat (BP2M) PCR yang telah mendanai penelitian ini dan Badan Perencanaan, Pengembangan, dan Penjaminan Mutu (BP3M) PCR yang telah menjadi objek penelitian ini.

\section{Referensi}

[1] K. Direktorat Penjaminan Mutu, Dirjen Belmawa, Pedoman Sistem Penjaminan Mutu Internal - Pend. Akademik, Vokasi, Profesi dan PJJ. 2018.

[2] G. W. Wicaksono and M. A. Al-Rizki, "Peningkatan Kualitas Evaluasi Mutu Akademik Universitas Muhammadiyah Malang melalui Sistem Informasi Mutu (SIMUTU)," Kinet. Game Technol. Inf. Syst. Comput. Network, Comput. Electron. Control, vol. 1, no. 1, pp. 1-8, 2018, doi: 10.22219/kinetik.v1i1.3.

[3] Adelin and H. Effendi, "Aplikasi Audit Mutu Akademik Internal dengan Pendekatan Extreme Programming," J. TI Atma Luhur, vol. 4, no. 1, pp. 13-24, 2017.

[4] D. R. Febriyanti and H. Irawan, "Penerapan Sistem Informasi Audit Mutu Internal Berbasis Web Guna Meningkatkan Efisiensi Kerja Studi Kasus: Lembaga Penjaminan Mutu Universitas Budi Luhur," J u r n a l I D E A L I S V, vol. 3, no. 1, pp. 474-480, 2020.

[5] M. Safi'i and Vidy, "Perancangan Sistem Informasi Badan Penjaminan Mutu," Metik, vol. 1, no. 2, pp. 1-7, 2017.

[6] T. H. K. Pudjiantoro Agus, "Sistem Informasi Audit Mutu Internal Satuan Penjaminan Mutu (SPM) Unjani," Seinasi-Kesi, no. Vol 1, No 1 (2018): Seinasi-Kesi 2018, pp. 76-81, 2018, [Online]. Available: https://conference.upnvj.ac.id/index.php/seinasikesi/article/view/40. 
[7] Yeni Nuraeni, "Perancangan Sistem Informasi Penjamian Mutu Perguruan Tinggi Bidang Sumber Daya Manusia," J. Informations Syst., vol. 6, no. 1, pp. 32-43, 2010.

[8] A. C. Nugraha and N. Syakrani, "Aplikasi Audit Mutu Internal Online Studi Kasus SPM Politeknik Negeri Bandung,” Difusi, vol. 1, no. 2, 2018.

[9] Elvin, M. Anggraini, and D. Pibriana, "Rancang Bangun Sistem Informasi Pengendalian Dokumen Dan AMI Pada BPM Kampus MDP,” no. x, pp. 1-12, 2012.

[10] F. I. Prasetyo, "Rancang Bangun Prototipe Sistem Infomrasi Eksekutif Institut Agama Islam Ibrahimy Menggunakan Standar Mutu BAN PT (Standar 3, 4 dan 5)," Malang, 2013.

[11] V. Rindengan, A. Lumenta, and Y. Rindengan, "Rancang Bangun Aplikasi Audit Mutu Akademik Internal Universitas Sam Ratulangi Berbasis Web," J. Tek. Inform., vol. 6, no. 1, pp. 1-6, 2015, doi: 10.35793/jti.6.1.2015.9979.

[12] A. Darmawan and M. Hasibuan, "Analisis Dan Perancangan Aplikasi Sistem Informasi Audit Mutu Internal Dan Dokumentasi Penjaminan Mutu Perguruan Tinggi," J. Generic, vol. 9, no. 2, pp. 342-347, 2014.

[13] A. Wibowo and A. Azimah, "Rancang Bangun Sistem Informasi Penjaminan Mutu Perguruan Tinggi Menggunakan Metode Throwaway Prototyping Development," in Seminar Nasional Teknologi Informasi dan Multimedia, 2016, pp. 103-108.

[14] A. Fikriyya and R. T. Dirgahayu, "Implementasi Prototyping dalam Perancangan Sistem Informasi Pendar Foundation Yogyakarta," Automata, vol. 1, no. 2, 2020.

[15] T. A. A. Kurniawan;, "Penerapan Metode Prototype dalam Pengembangan Sistem untuk Peracangan Aplikasi Web Jasa Restorasi pada PT Quantum Nusatama," J. Ilm. Fak. Tek. LIMIT' $S$, vol. 14, no. 1, pp. 1-12, 2018.

[16] K. Direktorat Penjaminan Mutu, Dirjen Belmawa, Pedoman Audit Mutu Internal (AMI), no. 367. 2018.

[17] I. Rinardo and S. Yulianto, "Pengembangan Sistem Audit Mutu Akademik Internal ( AMAI ) menggunakan Framework Bootstrap (Studi Kasus: Lembaga Penjaminan Mutu dan Audit Internal Universitas Kristen Satya Wacana) Artikel Ilmiah,” no. September, p. 2, 2016.

[18] D. Rolliawati, A. Yusuf, and A. S. Hamdani, "Desain Prototipe Sistem Informasi Penjaminan Mutu Internal Berbasis Standar Nasional Pendidikan Tinggi," in Seminar Nasional Inovasi dan Aplikasi Teknologi di Industri 2018, 2018, vol. 4, no. 1, pp. 167-173.

[19] R. Saputra, Eko; Mazalisa, Zanial; Andryani, "Usability Testing Untuk Mengukur Penggunaan Website Inspektorat Kota Palembang," J. Tek. Inform., no. 12, p. 12, 2014.

[20] J. Nielsen's Alertbox, "Usability 101: Introduction to Usability," Usability, vol. 101. 2003, [Online]. Available: http://tfa.stanford.edu/download/IntroToUsability.pdf. 